\title{
Review \\ Extracellular Vesicles in Acute Kidney Injury and Clinical Applications
}

\author{
Sekyung $\mathrm{Oh}^{1}{ }^{1}$ and Sang-Ho Kwon ${ }^{2, *(\mathbb{D})}$ \\ 1 Department of Medical Science, College of Medicine, Catholic Kwandong University, Incheon 22711, Korea \\ ohskjhmi@cku.ac.kr \\ 2 Department of Cellular Biology and Anatomy, Medical College of Georgia, Augusta University, \\ Augusta, GA 30912, USA \\ * Correspondence: KKWON@augusta.edu; Tel.: +1-706-721-0381
}

check for updates

Citation: Oh, S.; Kwon, S.-H. Extracellular Vesicles in Acute Kidney Injury and Clinical Applications. Int. J. Mol. Sci. 2021, 22, 8913. https:// doi.org/10.3390/ijms22168913

Academic Editor: Grazyna Nowak

Received: 30 July 2021

Accepted: 17 August 2021

Published: 18 August 2021

Publisher's Note: MDPI stays neutral with regard to jurisdictional claims in published maps and institutional affiliations.

Copyright: (c) 2021 by the authors. Licensee MDPI, Basel, Switzerland. This article is an open access article distributed under the terms and conditions of the Creative Commons Attribution (CC BY) license (https:// creativecommons.org/licenses/by/ $4.0 /)$.

\begin{abstract}
Acute kidney injury (AKI) - the sudden loss of kidney function due to tissue damage and subsequent progression to chronic kidney disease--has high morbidity and mortality rates and is a serious worldwide clinical problem. Current AKI diagnosis, which relies on measuring serum creatinine levels and urine output, cannot sensitively and promptly report on the state of damage. To address the shortcomings of these traditional diagnosis tools, several molecular biomarkers have been developed to facilitate the identification and ensuing monitoring of AKI. Nanosized membranebound extracellular vesicles (EVs) in body fluids have emerged as excellent sources for discovering such biomarkers. Besides this diagnostic purpose, EVs are also being extensively exploited to deliver therapeutic macromolecules to damaged kidney cells to ameliorate AKI. Consequently, many successful AKI biomarker findings and therapeutic applications based on EVs have been made. Here, we review our understanding of how EVs can help with the early identification and accurate monitoring of AKI and be used therapeutically. We will further discuss where current EV-based AKI diagnosis and therapeutic applications fall short and where future innovations could lead us.
\end{abstract}

Keywords: acute kidney injury; extracellular vesicles; exosomes; microvesicles; apoptotic bodies; biomarkers; liquid biopsy; mesenchymal stem cells; injury repair

\section{Introduction}

Unceasingly ridding the blood of metabolic waste and reabsorbing essential molecules into our body, the kidney controls body fluid volume, osmolarity, acid-base balance, electrolyte concentration, and toxic substance removal. In playing such vital roles, however, the kidney is often exposed to various endogenous or exogenous insults that can disturb this exquisitely maintained body-fluid homeostasis [1,2]. One such disordered clinical condition, acute kidney injury (AKI) is characterized by a sudden decline in normal function, resulting from injury to cells in the nephron $[1,3]$. Prevalent in hospitalized patients, AKI poses a serious clinical problem worldwide with high mortality and morbidity [1,3]. Developing a reliable AKI diagnosis and prognosis, therefore, must be actively pursued $[4,5]$.

Fluids such as blood and urine hold numerous membrane-bound, nanosized vesicles that are secreted by many cell types [6-8]. Such extracellular vesicles (EVs) contain a set of macromolecules that reflect the properties of the cells from which they are generated [6-8]. Shielded by the vesicle membrane from the hydrolyzing activity abundant in biological fluids, EV cargo macromolecules can also elicit biologically relevant responses when transported to proximate or remote target cells for uptake [6]. These characteristics of EVs have thus been exploited not only to examine the physiological or pathological states of EV-producing cells in varied biological contexts but also to deliver therapeutically potent, bioactive molecules, enclosed within EVs, to desired target cells [9]. Accordingly, recent advances on AKI research have also benefited from developments in biomarker discovery and engineering such as using EVs [10]. 
In that regard, we summarize our current understanding of how AKI is variously diagnosed; how EVs help us come up with better diagnoses and prognoses, apply EV knowledge to ameliorate AKI, and prepare EVs for translational and therapeutic purposes. We further discuss challenges associated with isolating and analyzing EVs.

\section{A Growing Demand for a Better Diagnosis of Acute Kidney Injury (AKI)}

A considerably large share of mortality and morbidity around the world is attributed to impaired kidney functions, and AKI is a dire form of such renal failure manifested as an abrupt reduction of the normal kidney function, resulting from an injury to cells in the nephron. A wide variety of intrinsic and extrinsic factors such as oxidative stress and drug abuse are known to cause AKI to develop within days [11]. It poses a serious clinical problem worldwide as it afflicts $10-15 \%$ of patients admitted to a hospital and more than $50 \%$ of patients in an intense care unit [12-14].

Even though the kidney is thought to have some ability to regenerate itself after injury [2], most AKI patients do completely recover but proceed to develop tubulointerstitial fibrosis and chronic renal inflammation, ultimately leading to chronic kidney disease (CKD) [11,15-17]. Moreover, AKI often complicates the clinical courses of the patients by requiring dialysis and prolonged hospitalization leading to high morbidity and mortality [3]. Therefore, early detection of AKI with accurate staging is crucial for selecting the proper treatment, which is currently limited to supportive care to prevent AKI from becoming aggravated.

AKI is typically diagnosed and staged by measuring changes in serum creatinine and urine $[18,19]$. Serum creatinine levels can be found elevated in AKI due to a diminished glomerular filtration rate (GFR), but they cannot sensitively report on damage to the kidney. In fact, since AKI predominantly affects the tubules in the nephron, such glomerular measurements as GFRs and their proxy, serum creatinine levels, would only indirectly indicate an injury in the tubule [5]. Thus, only after either GFR declines substantially or a tubular injury progresses considerably, will serum creatine levels noticeably rise. Importantly, alterations in serum creatine levels, per se, cannot account for how GFR declines or how AKI occurs [20]. Likewise, reduced urine output (oliguria), which is frequently found in AKI patients, can neither notify us of injury incidence promptly nor inform us of the underlying process.

Using such indirect AKI indicators as serum creatinine levels and urine output could further convolute AKI diagnosis and prognosis, for these measurements could easily be influenced by a patient's age, gender, diet, muscularity, hydration, and medication profile $[21,22]$. These current diagnostic limitations have thus prompted studies to discover and evaluate more sophisticated molecular biomarkers that would enable a timely diagnosis accurate, precise staging, and a better prognosis [21,22].

\section{Uncovering AKI Biomarkers}

Advances in state-of-the-art mass spectrometry analysis and other related molecular methodologies have led to uncovering several AKI molecular biomarkers. All these efforts aimed at discovering such candidate macromolecules would enable sensitive, early detection; help predict clinical courses of treatment; and facilitate therapeutic decisions [23]. Consequently, while not yet globally commonplace, select biomarkers have entered the clinical use stage in some countries. For example, L-FABP (liver-type fatty acid-binding protein) and NGAL (neutrophil gelatinase-associated lipocalin) are approved for use in Japan and Europe, respectively. The United States Food and Drug Administration (FDA) has authorized the use of a combination of TIMP-2 (tissue inhibitor of metalloproteinase-2) and IGFBP-7 (insulin growth factor binding protein-7) [24]. The FDA has also permitted a panel of such urinary biomarkers as KIM-1 (kidney injury molecule-1), Cystatin C, Clusterin, and $\beta$-2-microglobulin for preclinical use to detect nephrotoxicity [25]. Notably, many of these molecular AKI biomarkers can be acquired and analyzed in a non-invasive manner, for these are released into urine in response to injury [5]. 
Alongside such a procedural advantage, these AKI biomarkers can also inform us of the site of injury in the nephron, albeit roughly. For example, KIM-1, L-FABP, IGFBP-7, and TIMP-2 are known to come from the proximal tubule; UMOD (Uromodulin, also known as Tamm Horsfall Protein) from the loop of Henle; and NGAL from the distal tubule and the collecting duct [5]. As diverse tissue responses likely accompany AKI in the kidney, studies have also discovered biomarkers that report inflammation (e.g., MCP-1, OPN, and IL-18), fibrosis (e.g., TGF- $\beta$, and PIINP), and repair (e.g., EGF, YKL-40, and OPN) [5] in addition to those that indicate injury. Although these biomarkers can account for the presence or progression of injury in a manner rather non-specific to AKI, the information gained from them can complement what is attainable from using injury-reporting urinary AKI biomarkers.

The discoveries of the biomarkers described above have already shed light on improving the diagnosis and prognosis of AKI. The appropriate practice of these biomarkers can help predict the progression of AKI to CKD, discern kidney dysfunction and injury, and manage the clinical courses of AKI patients. It can also guide the selection of homogeneous patient groups to plan better clinical trials aimed at AKI. Nonetheless, one should still be cautious when interpreting the performance of these biomarkers, for their temporal profiles can fluctuate with such factors as time after injury, baseline renal injury, and subclinical kidney disease [20,26]. Hence, while improving the implementation of the known biomarkers, recent investigations have moved on to an alternative biomarker discovery basis, namely, extracellular vesicles in body fluids, for these likely hold and concentrate potentially informative macromolecules $[27,28]$.

\section{Extracellular Vesicles as a Basis for Biomarker Discovery}

The extracellular milieu consists of a myriad of macromolecule species that are produced and released by many cell types. While some macromolecules disperse only locally from the source cell after release, others can travel to distant locations, complicating tracing of the producing cell. Furthermore, certain macromolecule species, such as albumin and immunoglobulin in the blood plasma, are known to dominate the molecular profile of the body fluid [29], making the identification of other significant macromolecules at low levels challenging. Moreover, the hydrolyzing activity that degrades macromolecules with varying susceptibility abounds in the extracellular milieu [29]. Hence, complexity in the molecular composition of the extracellular space and the instability of extracellular macromolecules have impeded efforts to discover biomarkers in body fluids [29]. In this regard, the nanosized, membrane-bound extracellular vesicles (EVs) have intrigued researchers in various fields [30-32], for these may not only concentrate a subset of extracellular macromolecules to reduce the molecular population complexity but also shield them from hydrolyzing activity to permit consistent recovery.

Generated and released by most cell types in our body, EVs can be recovered from a variety of body fluids, including blood, urine, saliva, and cerebrospinal fluid [30-32]. Earlier studies revealed that some cell types such as erythrocytes can remove obsolete membrane proteins by excreting them on EVs, thereby remodeling intracellular membranes [33,34]. Adding to such a somewhat simple cell pruning role, recent studies have also ascribed numerous intercellular communication roles to EVs. Thus, they are now thought to mediate biological processes between cells, ranging from body patterning and immune response to tissue repair and tumor development [35,36], by transporting a set of proteins and nucleic acids to target cells.

Cell biological studies on EV biogenesis mechanisms have broadly categorized EVs into three major classes (Figure 1). The smallest exosomes (30-100 $\mathrm{nm}$ in diameter), are known to emerge through intricate intracellular membrane trafficking. The formation of the multivesicular endosomes (MVE, also known as the multivesicular bodies, MVB) is the key step in exosome-generating membrane trafficking (Figure 1) [37,38]; that is, the membrane of the late endosomes invaginates and pinches off, giving rise to numerous intraluminal vesicles (ILVs) inside the resulting outer surrounding vesicle, MVE. A specific 
set of macromolecules are thought to board ILVs during this process. Charged with these constituents, ILVs are eventually secreted as exosomes when the outer MVE membrane fuses to the plasma membrane $[37,38]$. Numerous factors are known to regulate exosome generation and release, including membrane trafficking proteins [39-41], the Rab family of small GTPases [42,43], the ESCRT-III (the endosomal sorting complex required for transport-III) machinery [44], the Sirtuin family of deacetylases [45,46], the tetraspanin family of membrane proteins [47], and certain lipids such as ceramide [48].

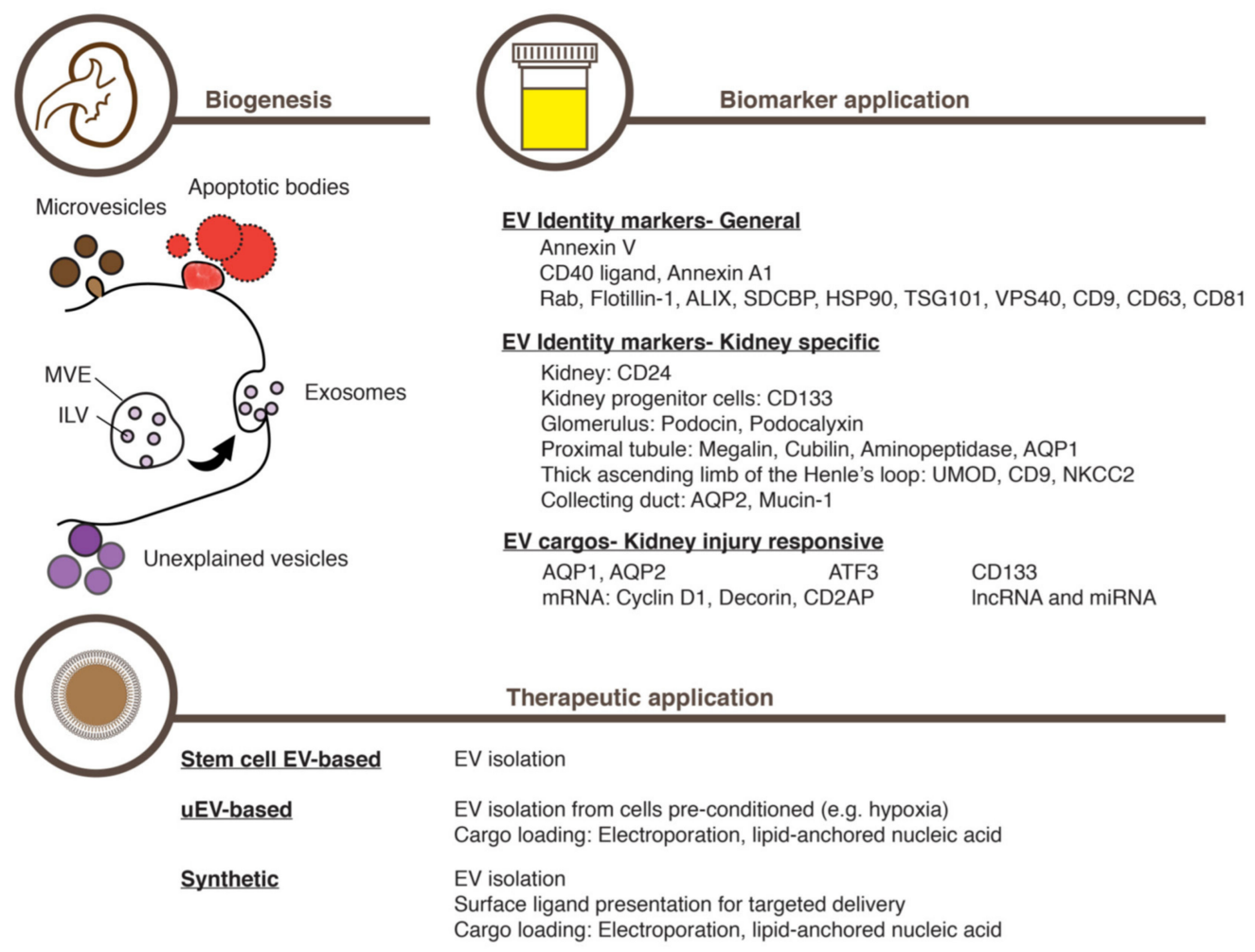

Figure 1. Generated by multiple mechanisms, extracellular vesicles (EVs) carry a set of macromolecules that reflect the normal and the pathological (e.g., acute kidney injury) states of the producing cells. EVs can also be engineered to deliver therapeutically potent, bioactive macromolecules to desired target cells. MVE, multivesicular endosome. ILV, intralumenal vesicle, uEV, urinary EV.

In contrast to this complexity of exosome biogenesis, the second EV class, microvesicles, is known to develop through a simpler process: the outward budding of the plasma membrane (Figure 1) [31,49]. While larger in size (100-1000 $\mathrm{nm}$ in diameter) than exosomes, microvesicles also pack and release a specific set of macromolecules as cargo. The third EV class, apoptotic bodies, are known to form when the membrane of an apoptotic bleb wraps many parts of the cell in relatively large vesicles of up to $4000 \mathrm{~nm}$ in diameter (Figure 1) [50]. To make matters more complex, recent studies are still uncovering novel EV classes as well as subclasses of a known EV type [51-54].

Existing in a continuum in size, density, and content [51], discerning these vesicles in the extracellular space seems difficult, however. The term EV is instead suggested to refer to all these vesicle types in the aggregate [30-32]. Nevertheless, one can still distinguish individual EV classes by using characteristic molecular markers (Figure 1). For example, Annexin V appears on the membrane of apoptotic bodies [52,55]; and CD40 ligand [56,57] and Annexin A1 [52] on that of medium-to-large EVs. Small EVs such as exosomes, on the other hand, are known to contain Rab proteins: Flotillin-1, the ESCRT-III machinery, ALIX, TSG101, and VPS4. Also, tetraspanins such as CD9, CD63, and CD81 are known to curve biological membranes, thereby favoring their existence on small EVs [31]. Furthermore, lipid composition also varies among EV classes, with sphingolipids such as sphingomyelin and ceramide existing mostly on small EVs [58]. 
EVs can deliver donor cell information to either proximate or remote cells. Not only individual macromolecules but also a subcellular organelle in its entirety such as a mitochondrium can be transferred via an EV to a target cell [59,60]. Several mechanisms, such as endocytosis and membrane fusion are known to unload EV contents in the target cell interior. The delivered macromolecules can, in turn, induce phenotypic alterations of the target cell. For example, certain transported messenger RNA (mRNA) molecules are translated into proteins, inducing de novo expression of the proteins in the target cell. On the other hand, microRNAs (miRNA) are also delivered via EVs to recipient cells to reduce the level of the target mRNAs, thereby decreasing their expression [61-64]. Phenotypic alterations can also be induced by unpacking proteinaceous EV cargos in the target cell interior. For example, proteins transported via EVs can confer the ability to either promote or suppress immune responses upon the receiving cell [65].

\section{Urinary Extracellular Vesicles Containing Information on the Kidney}

Urine fascinates EV researchers, for urinary EVs can be isolated and analyzed economically and conveniently in a non-invasive manner outside our body [66]. Moreover, mass spectrometry studies have found that urinary EVs can serve as an excellent source for biomarkers [67]. A majority of urinary EVs are released apically from the epithelial cells facing the tubular lumen. Urinary EVs can also come from other parts of the kidney that drain urine such as the collecting duct cells, podocytes and other glomerular, progenitor, and infiltrated inflammatory cells [68-72].

Studies have revealed that urinary EVs carry typical exosome markers, including tetraspanins (CD9, CD63, and CD81), Flotillin-1, HSP70, and ALIX (Apoptosis-linked gene2-interacting protein $X$ ), among others (Figure 1) [73]. Moreover, urinary EVs also express markers that denote the kidney origin such as CD24 (Figure 1) [74]. Other macromolecules in urinary EVs can further inform us of where in the kidney individual EVs originated, for example: Podocin and Podocalyxin come from podocytes in the glomerulus [75]; Megalin, Cubilin, Aminopeptidase [76], and Aquaporin-1 (AQP-1) come from the proximal tubule [77]; UMOD, CD9, and NKCC2 (Type $2 \mathrm{Na}-\mathrm{K}-2 \mathrm{Cl}$ co-transporter) are from the thick ascending limb of the Henle's loop; and AQP-2 (Aquaporin-2) and Mucin-1 are from the collecting duct (Figure 1) [71,78]. Moreover, the urinary EVs coming from renal progenitor cells can also be identified by detecting CD133 expression (Figure 1) [79,80]. In addition to these proteinaceous markers, urinary EVs harbor RNA molecules. While the majority of these RNAs are ribosomal and non-encoding [81], miRNAs and protein-coding mRNAs in urinary EVs are also implicated in regulating kidney functions (Figure 1) [82].

In addition to simply reflecting the status of the producing cells, urinary EVs may also mediate information exchange between cells in the nephron [83]. Since urine flows unidirectionally, EVs produced by proximal tubule cells may travel down the road along the tubule to induce phenotypic alterations in cells in the distal tubule and the collecting duct [84]. For example, EVs released from the proximal tubule cells treated with a dopamine receptor agonist can reduce radical production in the recipient distal tubule cells, thereby spreading an anti-inflammatory response across the nephron [84].

\section{Urinary Extracellular Vesicles in Acute Kidney Injury and Recovery}

Given the convenience and feasibility in uncovering biomarkers, urinary EVs are revealing several potentially useful macromolecules that report on AKI. Unlike serum creatinine levels and urine output, these macromolecules carried by urinary EVs appear to mirror promptly the injured state of the kidney, enabling more accurate disease staging, diagnosis, and prognosis (Figure 1). This advantage is exemplified by the ATF3 (Activating transcription factor 3) protein in urinary EVs, the level of which substantially increases in response to an acute injury induced by either cisplatin or ischemia-reperfusion (Figure 1) [69]. Interestingly, the ATF3 protein level increases in response to AKI specifically in urinary EVs but not in the urine per se [69], demonstrating the utility of EVs in concentrating and stabilizing extracellular macromolecules. Moreover, the rise of the ATF3 level in urinary 
EVs precedes that of serum creatinine, with the elevated level staying for 24-48 h [69], which suggests that timely registration of the damage can be achieved by measuring ATF3 protein levels in urinary EVs. The level of mRNAs encoding ATF3 was also elevated in urinary EVs after AKI induction [85]. Other potentially useful proteins in urinary EVs, the levels of which increase in response AKI prior to the rise in serum creatinine, include Fetuin-A [86] and NGAL [87]. On the other hand, the level of AQP-1 in urinary EVs, a marker of the proximal tubule, declines in response to ischemia-reperfusion-mediated acute kidney injury in rats as well as kidney transplantation in human patients [77].

Importantly, the content of urinary EVs changes while the damaged kidney is recovering from AKI as shown by phenotypic alterations in the nephron (Figure 1) [82]. For example, in rat kidney such miRNA cargo as miR-16, miR-24, and miR200c are released right after an acute ischemia-reperfusion injury [82]. In the following early recovery stage, a different set of miRNAs such as miR-9a, miR-141, miR-200a, miR-200c, and miR-429, which commonly target Zeb1/2 mRNA, are released, thereby engaging TGF- $\beta$-mediated fibrosis in the nephron during recovery from the injury [82]. The induced TGF- $\beta$ signaling, in turn, causes another set of miRNAs, miR-125a and miR-351, to be released [82].

The CD133-expressing progenitor cells in the kidney epithelium play key roles not only in continuous renewal of the kidney epithelium but also in recovery from AKI through regeneration of the damaged tissue (Figure 1) [88-91]. The number of CD133-expressing cells increases in response to an acute damage of the kidney [92,93]. Thus, the increase in cell number likely accounts for the increase in the number of CD133-containing EVs in urine [93]. These CD133-containing urinary EVs are thought to engage a certain gene expression program to promote cell cycle progression and survival, possibly transporting such cargo as Cyclin D1 and Decorin mRNAs (Figure 1) [94].

\section{Extracellular Vesicles from Mesenchymal Stem Cells for Treating AKI}

The utility of EVs goes beyond just cataloguing the contents and identifying informative molecules that report on disease features and progression. To keep abreast of such basic biological endeavors, various translational research fields also use EVs as a vehicle to deliver therapeutic molecules to specific, desired target cells. Accordingly, a great deal of research has explored the possibility of ameliorating renal diseases such as AKI by making use of EVs released from a homogeneous cell source: principally, mesenchymal stem cells (also known as mesenchymal stromal cells, MSCs), that can supply EVs quite consistently.

Derived from a variety of tissues such as bone marrow, adipose tissue, and the umbilical cord, MSCs commonly express such surface markers as CD44, CD73, CD90, CD105, and CD146 [95] and have been used in the treatment of various diseases, mainly through helping tissue regeneration [96]. However, attempts to implant MSCs stably in a targeted tissue have proven difficult to achieve [97-102]. Instead, it has become evident that a conditioned culture medium of MSCs can have therapeutic effects comparable to those of the transplanted cells, themselves [103-105]. Among the conditioned culture media of MSCs, EVs were proven to have therapeutic potential for a variety of diseases, including AKI (Figure 1) [106-109]. A recent meta-analysis of 31 independent preclinical rodent AKI models confirmed the therapeutic potential of MSC-derived EVs in treating AKI [110].

MSC-derived EVs appear to exert therapeutic effects through conferring upon the kidney cells the ability to resist the apoptosis of healthy epithelial cells [111,112], stimulate the recovery process such as cell-cycle reentry [111,112], and suppress inflammatory responses [107]. These effects are presumably based on transferring certain critical cargo molecules in the MSC-derived EVs to the injured tissue. In fact, delivering such factors as the IGF-1 (Insulin-like growth factor 1) protein and mRNA via MSC-derived EVs are well documented for their ability to regenerate a damaged kidney [113]. In addition, miRNAs transported by MSC-derived EVs may also play a crucial role in eliciting therapeutic effects for AKI. In MSCs, the knockdown of Drosha, an essential component in primary miRNA processing [114], can prevent therapeutic effects [115]. 
While EVs from a variety of MSC sources can assist recovery from AKI [116-122], this complexity of cell origin and the varied culture conditions may confound the efforts to purify or enrich EVs from the conditioned culture medium. Co-isolating substances present in the conditioned culture medium may lead to a wrong conclusion about the therapeutic potential expected from the EVs. Moreover, the adequate effective amount, route of delivery, and biodistribution of MSC-derived EVs need to be determined more definitively [123,124]. Even so, EVs derived from MSCs provide us with several advantages such as low immunogenicity [125-127], high biological tolerance [128], and rapid internalization into target cells [129].

\section{Preparing Extracellular Vesicles for Treating AKI}

When using EVs to treat diseases such as AKI, one should make careful decisions about where to obtain EVs, how to load EV cargos, and how to enrich EVs from heterogenous mixtures with consistent quality. While several MSC types may produce EVs of comparable effects, those that have similar characteristics to the renal system will likely be better at treating AKI. In the same vein, EVs derived from either renal progenitor cells or their differentiation progenies may excel those from other cell sources (Figure 1). The recent development of the protocol to differentiate human pluripotent stem cells into the kidney organoid could be utilized to generate a large quantity of homogenous EVs (Figure 1) [130]. Since pluripotent stem cells can be induced from somatic cells obtainable from the patient who would later want to receive an EV therapy, the EVs prepared using this approach could avoid many obstacles such as unwanted immune responses and ethical issues. Moreover, CRISPR/Cas9-mediated genome editing has shown its utility by precisely altering the genome of the pluripotent stem cells and, subsequently, that of their differentiated progenies in diverse research fields [131]. Employing this approach in AKI studies, therefore, would not only reveal definitively how individual genetic factors can modulate EVs and contribute to amelioration of AKI but also enable production of EVs tailored to the genetic make-ups of individual patients.

On the other hand, a great deal of engineering effort is being made to improve EV cargo loading and EV delivery to target cells (Figure 1). For example, the MSCs engineered to express the miRNA Let7c were found to localize preferentially to the injured kidney, resulting in an efficient transferring of Let7c in EVs to the damaged tissue to repress expression of the genes involved in TGF- $\beta$-mediated fibrosis [132]. EV engineering studies targeting other organs illuminates how to address AKI with engineered EVs. These include a fusion of the exosome membrane protein LAMP2B to the neuron-specific RVG peptide 3 to improve neuronal delivery [133], an enhanced stable retention of exosomes in circulation by expressing CD47 in MSCs [134], and the development of a novel molecular platform called ARMS (Arrestin domain containing protein 1-mediated microvesicles) to improve cargo packaging and delivery [135]. In this vein, a recent development of the specific delivery of erythrocyte-derived EVs charged with therapeutic small interfering RNAs (siRNAs) to the damaged kidney with AKI is remarkable [136]. The key to this feat was the development of synthetic peptides that bound to the AKI biomarker KIM-1 [136]. Expressing the peptides on the EVs derived from erythrocytes delivered the EVs charged with therapeutic siRNAs specifically to the AKI kidney, ameliorating tubulointerstitial inflammation and fibrosis [136].

In addition to utilizing intrinsic cell mechanisms of EV cargo loading, macromolecules of potential therapeutic values can also be introduced by incubating with isolated EVs in a test tube condition (Figure 1). Multiple methods have been explored to achieve this, including simple incubation, electroporation, and saponin-assisted loading [137]. Among these, simple incubation appears to work well for loading hydrophobic compounds [138] and proved its utility in delivering the organic compound curcumin [139]. On the other hand, electroporation was shown to be useful for loading exogenously prepared miRNAs [140] and long non-encoding RNA [141]. Moreover, the saponin-assisted encapsulation showed 
an enhanced delivering efficiency of the CRIPR/Cas components to the target cells, thereby facilitating precise genome editing [142].

\section{Challenges in Isolating and Analyzing Extracellular Vesicles}

Both basic biological and translational EV studies critically rely on methods to isolate EVs with high purity and consistency. While a variety has been developed, each has relative strengths and weaknesses. One should, therefore, understand what each method can offer and how to use them appropriately.

The most widely accepted method for EV isolation is multiple rounds of differential centrifugation and pelleting exosomes at the last ultracentrifugation step $[143,144]$. While this approach promises to isolate EVs at the purest level among the current methods, the whole process is laborious, time consuming, and limited in scalability. Also, ultrahigh gravitational forces can also cause EVs to aggregate, thereby potentially impairing their integrity [145]. Notably, ultracentrifugation of the conditioned culture medium may also pellet a substantial number of particles unrelated to EVs. In preparing EVs from a molecularly complex fluid, therefore, one might also consider further fractionating the EV fraction of ultracentrifugation by using another method such as density gradient centrifugation [146].

Separating particles by size is another approach for isolating EVs at a relatively pure level with varying scalability. This includes methodologies such as relying on either ultrafiltration concentration [147] or tangential flow filtration [148], often followed by size exclusion chromatography to purify EVs. In addition, various affinity capturing methods are widely used to isolate EVs, such as immunoaffinity capturing with anti-EpCAM and anti-CD63 antibodies [149]. However, immunoaffinity methods can only capture a subset of EVs, which express the antigen on the EV surface [150,151]. A similar affinity capturing method uses the interaction between phosphatidylserine on the surface of some EVs and Tim4 (T cell immunoglobulin and mucin domain protein 4) on capturing magnetic beads [151]. A recently developed affinity-based capturing method using lipid nanoprobes holds great promise in that it can isolate highly pure EVs with a much shorter processing time relative to differential centrifugations and with scales conducive for high-throughput screening and analysis [152]. On the other hand, polymer-mediated precipitation also appears useful for isolating EVs, particularly to confirm EV biomarker performance [153]. The high yield of EV isolation by this method, however, comes at a cost in that it can also precipitate a large amount of particles unrelated to EVs [154].

To be used in clinics, EVs must lack contaminating xenogeneic substances, which can be avoided through culturing the EV-producing cells in a defined culture medium [9]. EVs prepared for therapeutic purposes should also pass a high purity threshold to preserve the physical and functional integrity [155]. Moreover, for consistent production, EV isolation scales should be adjustable without compromising quality [155]. To this end, EV manufacturing processes are being devised by combining the advantages that different $\mathrm{EV}$ isolation methodologies can provide. For example, an EV isolation procedure with tangential flow filtration and size exclusion chromatography in succession might promise high purity, scalability, and reproducibility.

\section{Conclusions}

Although AKI remains as a serious clinical problem that threatens the lives of countless patients worldwide, the recent development in biomarker discovery and regenerative therapy based on EVs is rapidly advancing our understanding and treatment of this dreadful disease. However, we still need to upgrade our EV biomarker inventory by further discovering and detailing where the disease-reporting macromolecules are generated in the nephron, when and how each of these is released via EVs, and how the levels of these biomarkers change over time. This new information should not only enable a more precise diagnosis and prognosis of AKI patients, but in turn help us design better therapeutic applications of EVs. The continuous methodological innovations in cell culturing, vesicle 
isolation, cargo loading, specific delivery to the damaged kidney will gradually solve many obstacles remaining in utilizing EVs with adequate quantity and quality for AKI therapy. Rapid developments in precise genome editing with the CRISPR/Cas system and in patient-derived kidney organoids from the induced pluripotent stem cells will further accelerate our endeavors to treat this hard-to-cure disease.

Author Contributions: Writing-original draft preparation, S.O. and S.-H.K.; writing-review and editing, S.O. and S.-H.K. Both authors have read and agreed to the published version of the manuscript.

Funding: This research was funded by National Research Foundation of Korea, NRF-2018R1D1A1B07 045410 and NRF-2021R1A2C1011293 to S.O.; and by National Institutes of Health, NIDDK, DK120510 to S.-H.K.

Institutional Review Board Statement: Not applicable.

Informed Consent Statement: Not applicable.

Data Availability Statement: Not applicable.

Acknowledgments: The authors thank members of the Oh and the Kwon laboratories for critical reading of this manuscript.

Conflicts of Interest: The authors declare no conflict of interest.

\section{References}

1. He, L.; Wei, Q.; Liu, J.; Yi, M.; Liu, Y.; Liu, H.; Sun, L.; Peng, Y.; Liu, F.; Venkatachalam, M.A.; et al. AKI on CKD: Heightened injury, suppressed repair, and the underlying mechanisms. Kidney Int. 2017, 92, 1071-1083. [CrossRef] [PubMed]

2. Li, J.-S.; Li, B. Renal Fibrosis: Mechanisms and therapies. Adv. Exp. Med. Biol. 2019, 1165, 661-670. [CrossRef] [PubMed]

3. Roncoa, C.; Bellomo, R.; Kellum, J.A. Acute kidney injury. Lancet 2019, 394, 1949-1964. [CrossRef]

4. Maggio, S.; Polidori, E.; Ceccaroli, P.; Cioccoloni, A.; Stocchi, V.; Guescini, M. Urinary biomarkers, methods and protocols. Methods Mol. Biol. 2021, 2292, 153-172. [CrossRef]

5. Wen, Y.; Parikh, C.R. Current concepts and advances in biomarkers of acute kidney injury. Crit. Rev. Clin. Lab. Sci. 2021, 58, 1-24. [CrossRef] [PubMed]

6. Shah, R.; Patel, T.; Freedman, J.E. Circulating extracellular vesicles in human disease. New Engl. J. Med. 2018, 379, 958-966. [CrossRef] [PubMed]

7. Raposo, G.; Stoorvogel, W. Extracellular vesicles: Exosomes, microvesicles, and friends. J. Cell Biol. 2013, 200, 373-383. [CrossRef] [PubMed]

8. Meldolesi, J. Exosomes and ectosomes in intercellular communication. Curr. Biol. 2018, 28, R435-R444. [CrossRef]

9. Pachler, K.; Lener, T.; Streif, D.; Dunai, Z.A.; Desgeorges, A.; Feichtner, M.; Öller, M.; Schallmoser, K.; Rohde, E.; Gimona, M. A Good manufacturing practice-Grade standard protocol for exclusively human mesenchymal stromal cell-derived extracellular vesicles. Cytotherapy 2017, 19, 458-472. [CrossRef]

10. Ranghino, A.; Dimuccio, V.; Papadimitriou, E.; Bussolati, B. Extracellular vesicles in the urine: Markers and mediators of tissue damage and regeneration. Clin. Kidney J. 2015, 8, 23-30. [CrossRef]

11. Coca, S.G.; Singanamala, S.; Parikh, C.R. Chronic kidney disease after acute kidney injury: A systematic review and meta-analysis. Kidney Int. 2012, 81, 442-448. [CrossRef]

12. Hsu, C.-Y.; McCulloch, C.E.; Fan, D.; Ordoñez, J.D.; Chertow, G.M.; Go, A.S. Community-based incidence of acute renal failure. Kidney Int. 2007, 72, 208-212. [CrossRef] [PubMed]

13. Coca, S.G.; Yusuf, B.; Shlipak, M.G.; Garg, A.X.; Parikh, C.R. Long-term risk of mortality and other adverse outcomes after acute kidney injury: A systematic review and meta-analysis. Am. J. Kidney Dis. 2009, 53, 961-973. [CrossRef]

14. Mehta, R.L.; Cerdá, J.; Burdmann, E.A.; Tonelli, M.; García-García, G.; Jha, V.; Susantitaphong, P.; Rocco, M.; Vanholder, R.; Sever, M.S.; et al. International Society of Nephrology's 0 by 25 initiative for acute kidney injury (zero preventable deaths by 2025): A human rights case for nephrology. Lancet 2015, 385, 2616-2643. [CrossRef]

15. Meng, X.-M.; Nikolic-Paterson, D.J.; Lan, H.Y. Inflammatory processes in renal fibrosis. Nat. Rev. Nephrol. 2014, 10, $493-503$. [CrossRef] [PubMed]

16. Liu, J.; Kumar, S.; Dolzhenko, E.; Alvarado, G.F.; Guo, J.; Lu, C.; Chen, Y.; Li, M.; Dessing, M.C.; Parvez, R.K.; et al. Molecular characterization of the transition from acute to chronic kidney injury following ischemia/reperfusion. JCI Insight 2017, 2, e94716. [CrossRef]

17. Asvapromtada, S.; Sonoda, H.; Kinouchi, M.; Oshikawa, S.; Takahashi, S.; Hoshino, Y.; Sinlapadeelerdkul, T.; Yokota-Ikeda, N.; Matsuzaki, T.; Ikeda, M. Characterization of urinary exosomal release of aquaporin-1 and -2 after renal ischemia-reperfusion in rats. Am. J. Physiol. 2018, 314, F584-F601. [CrossRef] 
18. Mehta, R.L.; Kellum, J.A.; Shah, S.V.; Molitoris, B.A.; Ronco, C.; Warnock, D.G.; Levin, A.; Network, A.K.I. Acute kidney injury network: Report of an initiative to improve outcomes in acute kidney injury. Crit. Care 2007, 11, R31. [CrossRef]

19. Kellum, J.A.; Lameire, N.; Group, K.A.G.W. Diagnosis, evaluation, and management of acute kidney injury: A KDIGO summary (Part 1). Crit. Care 2013, 17, 204. [CrossRef]

20. Succar, L.; Pianta, T.J.; Davidson, T.; Pickering, J.W.; Endre, Z.H. Subclinical chronic kidney disease modifies the diagnosis of experimental acute kidney injury. Kidney Int. 2017, 92, 680-692. [CrossRef] [PubMed]

21. Westhuyzen, J.; Endre, Z.H.; Reece, G.; Reith, D.M.; Saltissi, D.; Morgan, T.J. Measurement of tubular enzymuria facilitates early detection of acute renal impairment in the intensive care unit. Nephrol. Dial. Transpl. 2003, 18, 543-551. [CrossRef]

22. Han, W.K.; Bailly, V.; Abichandani, R.; Thadhani, R.; Bonventre, J.V. Kidney injury molecule-1 (KIM-1): A novel biomarker for human renal proximal tubule injury. Kidney Int. 2002, 62, 237-244. [CrossRef]

23. Endre, Z.H.; Walker, R.J.; Pickering, J.W.; Shaw, G.M.; Frampton, C.M.; Henderson, S.J.; Hutchison, R.; Mehrtens, J.E.; Robinson, J.M.; Schollum, J.B.W.; et al. Early intervention with erythropoietin does not affect the outcome of acute kidney injury (the EARLYARF Trial). Kidney Int. 2010, 77, 1020-1030. [CrossRef]

24. Pickering, J.W.; Endre, Z.H. Bench to bedside: The next steps for biomarkers in acute kidney injury. Am. J. Physiol. 2016, 311, F717-F721. [CrossRef] [PubMed]

25. Dieterle, F.; Sistare, F.; Goodsaid, F.; Papaluca, M.; Ozer, J.S.; Webb, C.P.; Baer, W.; Senagore, A.; Schipper, M.J.; Vonderscher, J.; et al. Renal biomarker qualification submission: A Dialog between the FDA-EMEA and predictive safety testing consortium. Nat. Biotechnol. 2010, 28, 455-462. [CrossRef] [PubMed]

26. Endre, Z.H.; Pickering, J.W.; Walker, R.J.; Devarajan, P.; Edelstein, C.L.; Bonventre, J.V.; Frampton, C.M.; Bennett, M.R.; Ma, Q.; Sabbisetti, V.S.; et al. Improved performance of urinary biomarkers of acute kidney injury in the critically Ill by stratification for injury duration and baseline renal function. Kidney Int. 2011, 79, 1119-1130. [CrossRef]

27. Karpman, D.; Ståhl, A.; Arvidsson, I. Extracellular vesicles in renal disease. Nat. Rev. Nephrol. 2017, 13, 545-562. [CrossRef]

28. Pomatto, M.A.C.; Gai, C.; Bussolati, B.; Camussi, G. Extracellular vesicles in renal pathophysiology. Front. Mol. Biosci. 2017, 4, 37. [CrossRef] [PubMed]

29. Boukouris, S.; Mathivanan, S. Exosomes in bodily fluids are a highly stable resource of disease biomarkers. Proteom. Clin. Appl. 2015, 9, 358-367. [CrossRef] [PubMed]

30. Gould, S.J.; Raposo, G. As we wait: Coping with an imperfect nomenclature for extracellular vesicles. J. Extracell. Vesicles 2013, 2. [CrossRef]

31. Théry, C.; Witwer, K.W.; Aikawa, E.; Alcaraz, M.J.; Anderson, J.D.; Andriantsitohaina, R.; Antoniou, A.; Arab, T.; Archer, F.; Atkin-Smith, G.K.; et al. Minimal information for studies of extracellular vesicles 2018 (MISEV2018): A position statement of the international society for extracellular vesicles and update of the MISEV2014 guidelines. J. Extracell. Vesicles 2018, 8, 1535750. [CrossRef] [PubMed]

32. Witwer, K.W.; Théry, C. Extracellular vesicles or exosomes? On primacy, precision, and popularity influencing a choice of nomenclature. J. Extracell. Vesicles 2019, 8, 1648167. [CrossRef] [PubMed]

33. Pan, B.-T.; Johnstone, R.M. Fate of the transferrin receptor during maturation of sheep reticulocytes in vitro: Selective externalization of the receptor. Cell 1983, 33, 967-978. [CrossRef]

34. Harding, C.; Heuser, J.; Stahl, P. Receptor-mediated endocytosis of transferrin and recycling of the transferrin receptor in rat reticulocytes. J. Cell Biol. 1983, 97, 329-339. [CrossRef]

35. Bobrie, A.; Colombo, M.; Raposo, G.; Théry, C. Exosome secretion: Molecular mechanisms and roles in immune responses. Traffic 2011, 12, 1659-1668. [CrossRef]

36. Lakkaraju, A.; Rodriguez-Boulan, E. Itinerant exosomes: Emerging roles in cell and tissue polarity. Trends Cell Biol. 2008, 18, 199-209. [CrossRef]

37. Hessvik, N.P.; Llorente, A. Current knowledge on exosome biogenesis and release. Cell Mol. Life Sci. 2018, 75, 193-208. [CrossRef]

38. Colombo, M.; Raposo, G.; Théry, C. Biogenesis, secretion, and intercellular interactions of exosomes and other extracellular vesicles. Annu. Rev. Cell Dev. Biol. 2014, 30,1-35. [CrossRef]

39. Xiang, X.; Poliakov, A.; Liu, C.; Liu, Y.; Deng, Z.; Wang, J.; Cheng, Z.; Shah, S.V.; Wang, G.; Zhang, L.; et al. Induction of myeloid-derived suppressor cells by tumor exosomes. Int. J. Cancer 2009, 124, 2621-2633. [CrossRef] [PubMed]

40. Tamai, K.; Tanaka, N.; Nakano, T.; Kakazu, E.; Kondo, Y.; Inoue, J.; Shiina, M.; Fukushima, K.; Hoshino, T.; Sano, K.; et al. Exosome secretion of dendritic cells is regulated by Hrs, an ESCRT-0 protein. Biochem. Biophys. Res. Commun. 2010, 399, 384-390. [CrossRef]

41. Kwon, S.-H.; Oh, S.; Nacke, M.; Mostov, K.E.; Lipschutz, J.H. Adaptor protein CD2AP and L-type lectin LMAN2 regulate exosome cargo protein trafficking through the Golgi Complex. J. Biol. Chem. 2016, 291, 25462-25475. [CrossRef] [PubMed]

42. Savina, A.; Fader, C.M.; Damiani, M.T.; Colombo, M.I. Rab11 promotes docking and fusion of multivesicular bodies in a calcium-dependent manner. Traffic 2005, 6, 131-143. [CrossRef] [PubMed]

43. Ostrowski, M.; Carmo, N.B.; Krumeich, S.; Fanget, I.; Raposo, G.; Savina, A.; Moita, C.F.; Schauer, K.; Hume, A.N.; Freitas, R.P.; et al. Rab27a and Rab27b control different steps of the exosome secretion pathway. Nat. Cell Biol. 2010, 12, 19-30. [CrossRef]

44. Colombo, M.; Moita, C.; van Niel, G.; Kowal, J.; Vigneron, J.; Benaroch, P.; Manel, N.; Moita, L.F.; Théry, C.; Raposo, G. Analysis of ESCRT functions in exosome biogenesis, composition and secretion highlights the heterogeneity of extracellular vesicles. J. Cell Sci. 2013, 126, 5553-5565. [CrossRef] 
45. Lee, B.R.; Sanstrum, B.J.; Liu, Y.; Kwon, S.-H. Distinct role of sirtuin 1 (SIRT1) and sirtuin 2 (SIRT2) in inhibiting cargo-loading and release of extracellular vesicles. Sci. Rep. 2019, 9, 20049. [CrossRef] [PubMed]

46. Latifkar, A.; Ling, L.; Hingorani, A.; Johansen, E.; Clement, A.; Zhang, X.; Hartman, J.; Fischbach, C.; Lin, H.; Cerione, R.A.; et al. Loss of Sirtuin 1 Alters the secretome of breast cancer cells by impairing lysosomal integrity. Dev. Cell 2019, 49, 393.e7-408.e7. [CrossRef]

47. van Niel, G.; Charrin, S.; Simoes, S.; Romao, M.; Rochin, L.; Saftig, P.; Marks, M.S.; Rubinstein, E.; Raposo, G. The tetraspanin CD63 regulates ESCRT-independent and -dependent endosomal sorting during melanogenesis. Dev. Cell 2011, $21,708-721$. [CrossRef]

48. Trajkovic, K.; Hsu, C.; Chiantia, S.; Rajendran, L.; Wenzel, D.; Wieland, F.; Schwille, P.; Brügger, B.; Simons, M. Ceramide triggers budding of exosome vesicles into multivesicular endosomes. Science 2008, 319, 1244-1247. [CrossRef]

49. György, B.; Szabó, T.G.; Pásztói, M.; Pál, Z.; Misják, P.; Aradi, B.; László, V.; Pállinger, É.; Pap, E.; Kittel, Á.; et al. Membrane vesicles, current state-of-the-art: Emerging role of extracellular vesicles. Cell Mol. Life Sci. 2011, 68, 2667-2688. [CrossRef] [PubMed]

50. Andaloussi, S.E.; Mäger, I.; Breakefield, X.O.; Wood, M.J.A. Extracellular vesicles: Biology and emerging therapeutic opportunities. Nat. Rev. Drug Discov. 2013, 12, 347-357. [CrossRef] [PubMed]

51. Tkach, M.; Kowal, J.; Théry, C. Why the need and how to approach the functional diversity of extracellular vesicles. Philos. Trans. R. Soc. Lond. B Biol. Sci. 2018, 373, 20160479. [CrossRef]

52. Jeppesen, D.K.; Fenix, A.M.; Franklin, J.L.; Higginbotham, J.N.; Zhang, Q.; Zimmerman, L.J.; Liebler, D.C.; Ping, J.; Liu, Q.; Evans, R.; et al. Reassessment of exosome composition. Cell 2019, 177, 428.e18-445.e18. [CrossRef] [PubMed]

53. Zhang, H.; Freitas, D.; Kim, H.S.; Fabijanic, K.; Li, Z.; Chen, H.; Mark, M.T.; Molina, H.; Martin, A.B.; Bojmar, L.; et al. Identification of distinct nanoparticles and subsets of extracellular vesicles by asymmetric flow field-flow fractionation. Nat. Cell Biol. 2018, 20, 332-343. [CrossRef] [PubMed]

54. Zhang, M.; Schekman, R. Unconventional secretion, unconventional solutions. Science 2013, 340, 559-561. [CrossRef] [PubMed]

55. Crowley, L.C.; Marfell, B.J.; Scott, A.P.; Waterhouse, N.J. Quantitation of apoptosis and necrosis by annexin v binding, propidium iodide uptake, and flow cytometry. Cold Spring Harb. Protoc. 2016. [CrossRef]

56. Mathivanan, S.; Ji, H.; Simpson, R.J. Exosomes: Extracellular organelles important in intercellular communication. J. Proteom. 2010, 73, 1907-1920. [CrossRef]

57. Mobarrez, F.; Sjövik, C.; Soop, A.; Hållström, L.; Frostell, C.; Pisetsky, D.S.; Wallén, H. CD40L Expression in plasma of volunteers following LPS administration: A comparison between assay of CD40L on platelet microvesicles and soluble CD40L. Platelets 2014, 26, 486-490. [CrossRef]

58. Record, M.; Subra, C.; Silvente-Poirot, S.; Poirot, M. Exosomes as intercellular signalosomes and pharmacological effectors. Biochem. Pharmacol. 2011, 81, 1171-1182. [CrossRef]

59. Hough, K.P.; Trevor, J.L.; Strenkowski, J.G.; Wang, Y.; Chacko, B.K.; Tousif, S.; Chanda, D.; Steele, C.; Antony, V.B.; Dokland, T.; et al. Exosomal transfer of mitochondria from airway myeloid-derived regulatory cells to t cells. Redox Biol. 2018, 18, 54-64. [CrossRef]

60. Zhang, Y.; Tan, J.; Miao, Y.; Zhang, Q. The effect of extracellular vesicles on the regulation of mitochondria under hypoxia. Cell Death Dis. 2021, 12, 358. [CrossRef]

61. Valadi, H.; Ekström, K.; Bossios, A.; Sjöstrand, M.; Lee, J.J.; Lötvall, J.O. Exosome-mediated transfer of MRNAs and microRNAs is a novel mechanism of genetic exchange between cells. Nat. Cell Biol. 2007, 9, 654-659. [CrossRef]

62. Quesenberry, P.J.; Goldberg, L.R.; Aliotta, J.M.; Dooner, M.S.; Pereira, M.G.; Wen, S.; Camussi, G. Cellular phenotype and extracellular vesicles: Basic and clinical considerations. Stem Cells Dev. 2014, 23, 1429-1436. [CrossRef]

63. Pegtel, D.M.; Cosmopoulos, K.; Thorley-Lawson, D.A.; van Eijndhoven, M.A.J.; Hopmans, E.S.; Lindenberg, J.L.; de Gruijl, T.D.; Würdinger, T.; Middeldorp, J.M. Functional Delivery of Viral MiRNAs via Exosomes. Proc. Natl. Acad. Sci. USA 2010, 107, 6328-6333. [CrossRef] [PubMed]

64. Skog, J.; Würdinger, T.; van Rijn, S.; Meijer, D.H.; Gainche, L.; Sena-Esteves, M.; Curry, W.T.; Carter, B.S.; Krichevsky, A.M.; Breakefield, X.O. Glioblastoma microvesicles transport RNA and proteins that promote tumour growth and provide diagnostic biomarkers. Nat. Cell Biol. 2008, 10, 1470-1476. [CrossRef] [PubMed]

65. Chaput, N.; Théry, C. Exosomes: Immune properties and potential clinical implementations. Semin. Immunopathol. 2011, 33, 419-440. [CrossRef]

66. Vitorino, R.; Ferreira, R.; Guedes, S.; Amado, F.; Thongboonkerd, V. What can urinary exosomes tell us? Cell Mol. Life Sci. 2021, 78, 3265-3283. [CrossRef] [PubMed]

67. Beasley-Green, A. Urine proteomics in the era of mass spectrometry. Int. Neurourol. J. 2016, 20, S70-S75. [CrossRef]

68. Fang, D.Y.; King, H.W.; Li, J.Y.; Gleadle, J.M. Exosomes and the Kidney: Blaming the messenger. Nephrology 2013, 18, 1-10. [CrossRef] [PubMed]

69. Zhou, H.; Cheruvanky, A.; Hu, X.; Matsumoto, T.; Hiramatsu, N.; Cho, M.E.; Berger, A.; Leelahavanichkul, A.; Doi, K.; Chawla, L.S.; et al. Urinary exosomal transcription factors, a new class of biomarkers for renal disease. Kidney Int. 2008, 74, 613-621. [CrossRef]

70. Dear, J.W.; Street, J.M.; Bailey, M.A. Urinary exosomes: A reservoir for biomarker discovery and potential mediators of intrarenal signalling. Proteomics 2013, 13, 1572-1580. [CrossRef] [PubMed] 
71. Pisitkun, T.; Shen, R.-F.; Knepper, M.A. Identification and proteomic profiling of exosomes in human urine. Proc. Natl. Acad. Sci. USA 2004, 101, 13368-13373. [CrossRef] [PubMed]

72. Erdbrügger, U.; Le, T.H. Extracellular vesicles in renal diseases: More than novel biomarkers? J. Am. Soc. Nephrol. 2016, 27, 12-26. [CrossRef]

73. Nabhan, J.F.; Hu, R.; Oh, R.S.; Cohen, S.N.; Lu, Q. Formation and release of arrestin domain-containing protein 1-mediated microvesicles (ARMMs) at plasma membrane by recruitment of TSG101 protein. Proc. Natl. Acad. Sci. USA 2012, 109, 4146-4151. [CrossRef] [PubMed]

74. Keller, S.; Rupp, C.; Stoeck, A.; Runz, S.; Fogel, M.; Lugert, S.; Hager, H.-D.; Abdel-Bakky, M.S.; Gutwein, P.; Altevogt, P. CD24 is a marker of exosomes secreted into urine and amniotic fluid. Kidney Int. 2007, 72, 1095-1102. [CrossRef] [PubMed]

75. Hogan, M.C.; Johnson, K.L.; Zenka, R.M.; Charlesworth, M.C.; Madden, B.J.; Mahoney, D.W.; Oberg, A.L.; Huang, B.Q.; Leontovich, A.A.; Nesbitt, L.L.; et al. Subfractionation, characterization, and in-depth proteomic analysis of glomerular membrane vesicles in human urine. Kidney Int. 2014, 85, 1225-1237. [CrossRef] [PubMed]

76. Moon, P.; Lee, J.; You, S.; Kim, T.; Cho, J.; Kim, I.; Kwon, T.; Kim, C.; Park, S.; Hwang, D.; et al. Proteomic analysis of urinary exosomes from patients of early IgA nephropathy and thin basement membrane nephropathy. Proteomics 2011, 11, 2459-2475. [CrossRef] [PubMed]

77. Sonoda, H.; Yokota-Ikeda, N.; Oshikawa, S.; Kanno, Y.; Yoshinaga, K.; Uchida, K.; Ueda, Y.; Kimiya, K.; Uezono, S.; Ueda, A.; et al. Decreased abundance of urinary exosomal aquaporin-1 in renal ischemia-reperfusion injury. Am. J. Physiol. 2009, 297, F1006-F1016. [CrossRef]

78. Hoorn, E.J.; Pisitkun, T.; Zietse, R.; Gross, P.; Frokiaer, J.; Wang, N.S.; Gonzales, P.A.; Star, R.A.; Knepper, M.A. Prospects for urinary proteomics: Exosomes as a source of urinary biomarkers (review article). Nephrology 2005, 10, 283-290. [CrossRef]

79. Zhou, H.; Yuen, P.S.T.; Pisitkun, T.; Gonzales, P.A.; Yasuda, H.; Dear, J.W.; Gross, P.; Knepper, M.A.; Star, R.A. Collection, storage, preservation, and normalization of human urinary exosomes for biomarker discovery. Kidney Int. 2006, 69, 1471-1476. [CrossRef]

80. Gonzales, P.A.; Pisitkun, T.; Hoffert, J.D.; Tchapyjnikov, D.; Star, R.A.; Kleta, R.; Wang, N.S.; Knepper, M.A. Large-scale proteomics and phosphoproteomics of urinary exosomes. J. Am. Soc. Nephrol. 2009, 20, 363-379. [CrossRef]

81. Miranda, K.C.; Bond, D.T.; Levin, J.Z.; Adiconis, X.; Sivachenko, A.; Russ, C.; Brown, D.; Nusbaum, C.; Russo, L.M. Massively parallel sequencing of human urinary exosome/microvesicle RNA reveals a predominance of non-coding RNA. PLoS ONE 2014, 9, e96094. [CrossRef]

82. Sonoda, H.; Lee, B.R.; Park, K.-H.; Nihalani, D.; Yoon, J.-H.; Ikeda, M.; Kwon, S.-H. MiRNA profiling of urinary exosomes to assess the progression of acute kidney injury. Sci Rep. 2019, 9, 4692. [CrossRef] [PubMed]

83. Hogan, M.C.; Manganelli, L.; Woollard, J.R.; Masyuk, A.I.; Masyuk, T.V.; Tammachote, R.; Huang, B.Q.; Leontovich, A.A.; Beito, T.G.; Madden, B.J.; et al. Characterization of PKD protein-positive exosome-like vesicles. J. Am. Soc. Nephrol. 2009, 20, 278-288. [CrossRef] [PubMed]

84. Gildea, J.J.; Seaton, J.E.; Victor, K.G.; Reyes, C.M.; Wang, D.B.; Pettigrew, A.C.; Courtner, C.E.; Shah, N.; Tran, H.T.; Sciver, R.E.V.; et al. Exosomal transfer from human renal proximal tubule cells to distal tubule and collecting duct cells. Clin. Biochem. 2014, 47, 89-94. [CrossRef] [PubMed]

85. Chen, H.; Lai, P.; Lan, Y.; Cheng, C.; Zhong, W.; Lin, Y.; Chen, T.; Lin, H. Exosomal ATF3 RNA attenuates pro-inflammatory gene MCP-1 transcription in renal ischemia-reperfusion. J. Cell Physiol. 2014, 229, 1202-1211. [CrossRef]

86. Zhou, H.; Pisitkun, T.; Aponte, A.; Yuen, P.S.T.; Hoffert, J.D.; Yasuda, H.; Hu, X.; Chawla, L.; Shen, R.-F.; Knepper, M.A.; et al. Exosomal fetuin-a identified by proteomics: A novel urinary biomarker for detecting acute kidney injury. Kidney Int. 2006, 70, 1847-1857. [CrossRef]

87. Alvarez, S.; Suazo, C.; Boltansky, A.; Ursu, M.; Carvajal, D.; Innocenti, G.; Vukusich, A.; Hurtado, M.; Villanueva, S.; Carreño, J.E.; et al. Urinary exosomes as a source of kidney dysfunction biomarker in renal transplantation. Transplant. Proc. 2013, 45, 3719-3723. [CrossRef]

88. Bussolati, B.; Bruno, S.; Grange, C.; Buttiglieri, S.; Deregibus, M.C.; Cantino, D.; Camussi, G. Isolation of renal progenitor cells from adult human kidney. Am. J. Pathol. 2005, 166, 545-555. [CrossRef]

89. Sagrinati, C.; Netti, G.S.; Mazzinghi, B.; Lazzeri, E.; Liotta, F.; Frosali, F.; Ronconi, E.; Meini, C.; Gacci, M.; Squecco, R.; et al. Isolation and characterization of multipotent progenitor cells from the bowman's capsule of adult human kidneys. J. Am. Soc. Nephrol. 2006, 17, 2443-2456. [CrossRef] [PubMed]

90. Bussolati, B.; Moggio, A.; Collino, F.; Aghemo, G.; D’Armento, G.; Grange, C.; Camussi, G. Hypoxia modulates the undifferentiated phenotype of human renal inner medullary CD133+ progenitors through Oct4/MiR-145 balance. Am. J. Physiol. 2012, 302, F116-F128. [CrossRef]

91. Dziedzic, K.; Pleniceanu, O.; Dekel, B. Kidney stem cells in development, regeneration and cancer. Semin. Cell Dev. Biol. 2014, 36, 57-65. [CrossRef] [PubMed]

92. Loverre, A.; Capobianco, C.; Ditonno, P.; Battaglia, M.; Grandaliano, G.; Schena, F.P. Increase of proliferating renal progenitor cells in acute tubular necrosis underlying delayed graft function. Transplantation 2008, 85, 1112-1119. [CrossRef]

93. Smeets, B.; Boor, P.; Dijkman, H.; Sharma, S.V.; Jirak, P.; Mooren, F.; Berger, K.; Bornemann, J.; Gelman, I.H.; Floege, J.; et al. Proximal tubular cells contain a phenotypically distinct, scattered cell population involved in tubular regeneration. J. Pathol. 2013, 229, 645-659. [CrossRef] 
94. Sallustio, F.; Costantino, V.; Cox, S.N.; Loverre, A.; Divella, C.; Rizzi, M.; Schena, F.P. Human renal stem/progenitor cells repair tubular epithelial cell injury through TLR2-driven inhibin-A and microvesicle-shuttled decorin. Kidney Int. 2013, 83, $392-403$. [CrossRef]

95. Bruno, S.; Tapparo, M.; Collino, F.; Chiabotto, G.; Deregibus, M.C.; Lindoso, R.S.; Neri, F.; Kholia, S.; Giunti, S.; Wen, S.; et al. Renal regenerative potential of different extracellular vesicle populations derived from bone marrow mesenchymal stromal cells. Tissue Eng. Pt. A 2017, 23, 1262-1273. [CrossRef] [PubMed]

96. Rohban, R.; Pieber, T.R. Mesenchymal stem and progenitor cells in regeneration: Tissue specificity and regenerative potential. Stem Cells Int. 2017, 2017, 5173732. [CrossRef]

97. Brennan, M.Á.; Renaud, A.; Amiaud, J.; Rojewski, M.T.; Schrezenmeier, H.; Heymann, D.; Trichet, V.; Layrolle, P. Pre-clinical studies of bone regeneration with human bone marrow stromal cells and biphasic calcium phosphate. Stem Cell Res. Ther. 2014, 5, 114. [CrossRef] [PubMed]

98. von Bahr, L.; Batsis, I.; Moll, G.; Hägg, M.; Szakos, A.; Sundberg, B.; Uzunel, M.; Ringden, O.; Blanc, K.L. Analysis of tissues following mesenchymal stromal cell therapy in humans indicates limited long-term engraftment and no ectopic tissue formation. Stem Cells 2012, 30, 1575-1578. [CrossRef]

99. Caplan, A.I.; Dennis, J.E. Mesenchymal stem cells as trophic mediators. J. Cell Biochem. 2006, 98, 1076-1084. [CrossRef] [PubMed]

100. Bochon, B.; Kozubska, M.; Surygała, G.; Witkowska, A.; Kuźniewicz, R.; Grzeszczak, W.; Wystrychowski, G. Mesenchymal stem cells-Potential applications in kidney diseases. Int. J. Mol. Sci. 2019, 20, 2462. [CrossRef] [PubMed]

101. Matthay, M.A.; Pati, S.; Lee, J. Concise review: Mesenchymal stem (stromal) cells: Biology and preclinical evidence for therapeutic potential for organ dysfunction following trauma or sepsis. Stem Cells 2017, 35, 316-324. [CrossRef]

102. Jong, O.G.D.; Balkom, B.W.M.V.; Schiffelers, R.M.; Bouten, C.V.C.; Verhaar, M.C. Extracellular vesicles: Potential roles in regenerative medicine. Front. Immunol. 2014, 5, 608. [CrossRef] [PubMed]

103. Miller, F.D. Riding the waves: Neural and nonneural origins for mesenchymal stem cells. Cell Stem Cell 2007, 1, 129-130. [CrossRef] [PubMed]

104. Van Koppen, A.; Joles, J.A.; van Balkom, B.W.M.; Lim, S.K.; Kleijn, D.; Giles, R.H.; Verhaar, M.C. Human embryonic mesenchymal stem cell-derived conditioned medium rescues kidney function in rats with established chronic kidney disease. PLoS ONE 2012, 7, e38746. [CrossRef]

105. Mendt, M.; Rezvani, K.; Shpall, E. Mesenchymal stem cell-derived exosomes for clinical use. Bone Marrow Transpl. 2019, 54, 789-792. [CrossRef]

106. Gatti, S.; Bruno, S.; Deregibus, M.C.; Sordi, A.; Cantaluppi, V.; Tetta, C.; Camussi, G. Microvesicles derived from human adult mesenchymal stem cells protect against ischaemia-Reperfusion-induced acute and chronic kidney injury. Nephrol. Dial. Transpl. 2011, 26, 1474-1483. [CrossRef] [PubMed]

107. Bruno, S.; Grange, C.; Collino, F.; Deregibus, M.C.; Cantaluppi, V.; Biancone, L.; Tetta, C.; Camussi, G. Microvesicles derived from mesenchymal stem cells enhance survival in a lethal model of acute kidney injury. PLoS ONE 2012, 7, e33115. [CrossRef] [PubMed]

108. Shen, B.; Liu, J.; Zhang, F.; Wang, Y.; Qin, Y.; Zhou, Z.; Qiu, J.; Fan, Y. CCR2 positive exosome released by mesenchymal stem cells suppresses macrophage functions and alleviates ischemia/reperfusion-induced renal injury. Stem Cells Int. 2016, $2016,1240301$. [CrossRef]

109. Grange, C.; Iampietro, C.; Bussolati, B. Stem cell extracellular vesicles and kidney injury. Stem Cell Investig. 2017, 4, 90. [CrossRef]

110. Liu, C.; Wang, J.; Hu, J.; Fu, B.; Mao, Z.; Zhang, H.; Cai, G.; Chen, X.; Sun, X. Extracellular vesicles for acute kidney injury in preclinical rodent models: A meta-analysis. Stem Cell Res. Ther. 2020, 11, 11. [CrossRef]

111. Bi, B.; Schmitt, R.; Israilova, M.; Nishio, H.; Cantley, L.G. Stromal cells protect against acute tubular injury via an endocrine effect. J. Am. Soc. Nephrol. 2007, 18, 2486-2496. [CrossRef]

112. Bruno, S.; Grange, C.; Deregibus, M.C.; Calogero, R.A.; Saviozzi, S.; Collino, F.; Morando, L.; Busca, A.; Falda, M.; Bussolati, B.; et al. Mesenchymal stem cell-derived microvesicles protect against acute tubular injury. J. Am. Soc. Nephrol. 2009, 20, $1053-1067$. [CrossRef] [PubMed]

113. Tomasoni, S.; Longaretti, L.; Rota, C.; Morigi, M.; Conti, S.; Gotti, E.; Capelli, C.; Introna, M.; Remuzzi, G.; Benigni, A. Transfer of growth factor receptor mrna via exosomes unravels the regenerative effect of mesenchymal stem cells. Stem Cells Dev. 2013, 22, 772-780. [CrossRef] [PubMed]

114. Kim, V.N.; Han, J.; Siomi, M.C. Biogenesis of small RNAs in animals. Nat. Rev. Mol. Cell Biol. 2009, 10, 126-139. [CrossRef]

115. Collino, F.; Bruno, S.; Incarnato, D.; Dettori, D.; Neri, F.; Provero, P.; Pomatto, M.; Oliviero, S.; Tetta, C.; Quesenberry, P.J.; et al. AKI recovery induced by mesenchymal stromal cell-derived extracellular vesicles carrying microRNAs. J. Am. Soc. Nephrol. 2015, 26, 2349-2360. [CrossRef] [PubMed]

116. Zhou, Y.; Xu, H.; Xu, W.; Wang, B.; Wu, H.; Tao, Y.; Zhang, B.; Wang, M.; Mao, F.; Yan, Y.; et al. Exosomes released by human umbilical cord mesenchymal stem cells protect against cisplatin-induced renal oxidative stress and apoptosis in vivo and in vitro. Stem Cell Res. Ther. 2013, 4, 34. [CrossRef]

117. Zou, X.; Zhang, G.; Cheng, Z.; Yin, D.; Du, T.; Ju, G.; Miao, S.; Liu, G.; Lu, M.; Zhu, Y. Microvesicles derived from human wharton's jelly mesenchymal stromal cells ameliorate renal ischemia-reperfusion injury in rats by suppressing CX3CL1. Stem Cell Res. Ther. 2014, 5, 40. [CrossRef] 
118. Ju, G.; Cheng, J.; Zhong, L.; Wu, S.; Zou, X.; Zhang, G.; Gu, D.; Miao, S.; Zhu, Y.; Sun, J.; et al. Microvesicles derived from human umbilical cord mesenchymal stem cells facilitate tubular epithelial cell dedifferentiation and growth via hepatocyte growth factor induction. PLoS ONE 2015, 10, e0121534. [CrossRef]

119. Gu, D.; Zou, X.; Ju, G.; Zhang, G.; Bao, E.; Zhu, Y. Mesenchymal stromal cells derived extracellular vesicles ameliorate acute renal ischemia reperfusion injury by inhibition of mitochondrial fission through MiR-30. Stem Cells Int. 2016, 2016, 2093940. [CrossRef]

120. Ranghino, A.; Bruno, S.; Bussolati, B.; Moggio, A.; Dimuccio, V.; Tapparo, M.; Biancone, L.; Gontero, P.; Frea, B.; Camussi, G. The effects of glomerular and tubular renal progenitors and derived extracellular vesicles on recovery from acute kidney injury. Stem Cell Res. Ther. 2017, 8, 24. [CrossRef]

121. Choi, H.Y.; Moon, S.J.; Ratliff, B.B.; Ahn, S.H.; Jung, A.; Lee, M.; Lee, S.; Lim, B.J.; Kim, B.S.; Plotkin, M.D.; et al. Microparticles from kidney-derived mesenchymal stem cells act as carriers of proangiogenic signals and contribute to recovery from acute kidney injury. PLoS ONE 2014, 9, e87853. [CrossRef] [PubMed]

122. Sanchez, M.B.H.; Bruno, S.; Grange, C.; Tapparo, M.; Cantaluppi, V.; Tetta, C.; Camussi, G. Human liver stem cells and derived extracellular vesicles improve recovery in a murine model of acute kidney injury. Stem Cell Res. Ther. 2014, 5, 124. [CrossRef]

123. Grange, C.; Skovronova, R.; Marabese, F.; Bussolati, B. Stem cell-derived extracellular vesicles and kidney regeneration. Cells 2019, 8, 1240. [CrossRef] [PubMed]

124. Borgovan, T.; Crawford, L.; Nwizu, C.; Quesenberry, P. Stem Cells and extracellular vesicles: Biological regulators of physiology and disease. Am. J. Physiol. Cell Physiol. 2019, 317, C155-C166. [CrossRef] [PubMed]

125. Lou, G.; Chen, Z.; Zheng, M.; Liu, Y. Mesenchymal stem cell-derived exosomes as a new therapeutic strategy for liver diseases. Exp. Mol. Med. 2017, 49, e346. [CrossRef] [PubMed]

126. Börger, V.; Bremer, M.; Ferrer-Tur, R.; Gockeln, L.; Stambouli, O.; Becic, A.; Giebel, B. Mesenchymal stem/stromal cell-derived extracellular vesicles and their potential as novel immunomodulatory therapeutic agents. Int. J. Mol. Sci. 2017, 18, 1450. [CrossRef] [PubMed]

127. Lai, R.C.; Tan, S.S.; Teh, B.J.; Sze, S.K.; Arslan, F.; de Kleijn, D.P.; Choo, A.; Lim, S.K. Proteolytic potential of the MSC exosome proteome: Implications for an exosome-mediated delivery of therapeutic proteasome. Int. J. Proteomics 2012, $2012,971907$. [CrossRef] [PubMed]

128. Murphy, D.E.; de Jong, O.G.; Brouwer, M.; Wood, M.J.; Lavieu, G.; Schiffelers, R.M.; Vader, P. Extracellular vesicle-based therapeutics: Natural versus engineered targeting and trafficking. Exp. Mol. Med. 2019, 51, 1-12. [CrossRef]

129. Kooijmans, S.A.A.; Schiffelers, R.M.; Zarovni, N.; Vago, R. Modulation of tissue tropism and biological activity of exosomes and other extracellular vesicles: New nanotools for cancer treatment. Pharmacol. Res. 2016, 111, 487-500. [CrossRef]

130. Takasato, M.; Er, P.X.; Chiu, H.S.; Little, M.H. Generation of kidney organoids from human pluripotent stem cells. Nat. Protoc. 2016, 11, 1681-1692. [CrossRef]

131. Termglinchan, V.; Seeger, T.; Chen, C.; Wu, J.C.; Karakikes, I. Cardiac gene therapy, methods and protocols. Methods Mol. Biol. 2017, 1521, 55-68. [CrossRef] [PubMed]

132. Wang, B.; Yao, K.; Huuskes, B.M.; Shen, H.-H.; Zhuang, J.; Godson, C.; Brennan, E.P.; Wilkinson-Berka, J.L.; Wise, A.F.; Ricardo, S.D. Mesenchymal stem cells deliver exogenous microRNA-Let7c via exosomes to attenuate renal fibrosis. Mol. Ther. 2016, 24, 1290-1301. [CrossRef]

133. Alvarez-Erviti, L.; Seow, Y.; Yin, H.; Betts, C.; Lakhal, S.; Wood, M.J.A. Delivery of SiRNA to the mouse brain by systemic injection of targeted exosomes. Nat. Biotechnol. 2011, 29, 341-345. [CrossRef] [PubMed]

134. Kamerkar, S.; LeBleu, V.S.; Sugimoto, H.; Yang, S.; Ruivo, C.F.; Melo, S.A.; Lee, J.J.; Kalluri, R. Exosomes facilitate therapeutic targeting of oncogenic KRAS in pancreatic cancer. Nature 2017, 18, 4249. [CrossRef]

135. Wang, Q.; Yu, J.; Kadungure, T.; Beyene, J.; Zhang, H.; Lu, Q. ARMMs as a versatile platform for intracellular delivery of macromolecules. Nat. Commun. 2018, 9, 960. [CrossRef] [PubMed]

136. Tang, T.-T.; Wang, B.; Li, Z.-L.; Wen, Y.; Feng, S.-T.; Wu, M.; Liu, D.; Cao, J.-Y.; Yin, Q.; Yin, D.; et al. Kim-1 targeted extracellular vesicles: A new therapeutic platform for RNAi to treat AKI. J. Am. Soc. Nephrol. 2021. [CrossRef]

137. Fuhrmann, G.; Serio, A.; Mazo, M.; Nair, R.; Stevens, M.M. Active loading into extracellular vesicles significantly improves the cellular uptake and photodynamic effect of porphyrins. J. Control. Release 2015, 205, 35-44. [CrossRef]

138. Ohno, S.; Takanashi, M.; Sudo, K.; Ueda, S.; Ishikawa, A.; Matsuyama, N.; Fujita, K.; Mizutani, T.; Ohgi, T.; Ochiya, T.; et al. Systemically injected exosomes targeted to EGFR deliver antitumor microRNA to breast cancer cells. Mol. Ther. 2013, $21,185-191$. [CrossRef]

139. Sun, D.; Zhuang, X.; Xiang, X.; Liu, Y.; Zhang, S.; Liu, C.; Barnes, S.; Grizzle, W.; Miller, D.; Zhang, H.-G. A novel nanoparticle drug delivery system: The anti-inflammatory activity of curcumin is enhanced when encapsulated in exosomes. Mol. Ther. 2010, 18, 1606-1614. [CrossRef]

140. Pomatto, M.A.C.; Bussolati, B.; D'Antico, S.; Ghiotto, S.; Tetta, C.; Brizzi, M.F.; Camussi, G. Improved loading of plasma-derived extracellular vesicles to encapsulate antitumor MiRNAs. Mol. Ther. Methods Clin. Dev. 2019, 13, 133-144. [CrossRef]

141. Tao, S.-C.; Rui, B.-Y.; Wang, Q.-Y.; Zhou, D.; Zhang, Y.; Guo, S.-C. Extracellular vesicle-mimetic nanovesicles transport lncRNAH19 as competing endogenous RNA for the treatment of diabetic wounds. Drug Deliv. 2018, 25, 241-255. [CrossRef]

142. Lainšček, D.; Kadunc, L.; Keber, M.M.; Bratkovič, I.H.; Romih, R.; Jerala, R. Delivery of an artificial transcription regulator DCas9-VPR by extracellular vesicles for therapeutic gene activation. ACS Synth. Biol. 2018, 7, 2715-2725. [CrossRef] [PubMed] 
143. Théry, C.; Amigorena, S.; Raposo, G.; Clayton, A. Isolation and characterization of exosomes from cell culture supernatants and biological fluids. Curr. Protoc. Cell Biol. 2006, 30, 3.22.1-3.22.29. [CrossRef] [PubMed]

144. Gardiner, C.; Vizio, D.D.; Sahoo, S.; Théry, C.; Witwer, K.W.; Wauben, M.; Hill, A.F. Techniques used for the isolation and characterization of extracellular vesicles: Results of a worldwide survey. J. Extracell. Vesicles 2016, 5, 32945. [CrossRef] [PubMed]

145. Linares, R.; Tan, S.; Gounou, C.; Arraud, N.; Brisson, A.R. High-speed centrifugation induces aggregation of extracellular vesicles. J. Extracell. Vesicles 2015, 4, 29509. [CrossRef] [PubMed]

146. Iwai, K.; Minamisawa, T.; Suga, K.; Yajima, Y.; Shiba, K. Isolation of human salivary extracellular vesicles by iodixanol density gradient ultracentrifugation and their characterizations. J. Extracell. Vesicles 2016, 5, 30829. [CrossRef] [PubMed]

147. Cheruvanky, A.; Zhou, H.; Pisitkun, T.; Kopp, J.B.; Knepper, M.A.; Yuen, P.S.T.; Star, R.A. Rapid isolation of urinary exosomal biomarkers using a nanomembrane ultrafiltration concentrator. Am. J. Physiol. Renal 2007, 292, F1657-F1661. [CrossRef] [PubMed]

148. Heinemann, M.L.; Ilmer, M.; Silva, L.P.; Hawke, D.H.; Recio, A.; Vorontsova, M.A.; Alt, E.; Vykoukal, J. Benchtop isolation and characterization of functional exosomes by sequential filtration. J. Chromatogr. A 2014, 1371, 125-135. [CrossRef] [PubMed]

149. Tauro, B.J.; Greening, D.W.; Mathias, R.A.; Ji, H.; Mathivanan, S.; Scott, A.M.; Simpson, R.J. Comparison of ultracentrifugation, density gradient separation, and immunoaffinity capture methods for isolating human colon cancer cell line LIM1863-derived exosomes. Methods 2012, 56, 293-304. [CrossRef]

150. Willms, E.; Johansson, H.J.; Mäger, I.; Lee, Y.; Blomberg, K.E.M.; Sadik, M.; Alaarg, A.; Smith, C.I.E.; Lehtiö, J.; Andaloussi, S.E.; et al. Cells release subpopulations of exosomes with distinct molecular and biological properties. Sci. Rep. 2016, 6, 22519. [CrossRef] [PubMed]

151. Wiklander, O.P.B.; Bostancioglu, R.B.; Welsh, J.A.; Zickler, A.M.; Murke, F.; Corso, G.; Felldin, U.; Hagey, D.W.; Evertsson, B.; Liang, X.-M.; et al. Systematic methodological evaluation of a multiplex bead-based flow cytometry assay for detection of extracellular vesicle surface signatures. Front. Immunol. 2018, 9, 1326. [CrossRef] [PubMed]

152. Wan, Y.; Cheng, G.; Liu, X.; Hao, S.-J.; Nisic, M.; Zhu, C.-D.; Xia, Y.-Q.; Li, W.-Q.; Wang, Z.-G.; Zhang, W.-L.; et al. Rapid magnetic isolation of extracellular vesicles via lipid-based nanoprobes. Nat. Biomed. Eng. 2017, 1, 0058. [CrossRef] [PubMed]

153. Kordelas, L.; Rebmann, V.; Ludwig, A.-K.; Radtke, S.; Ruesing, J.; Doeppner, T.R.; Epple, M.; Horn, P.A.; Beelen, D.W.; Giebel, B. MSC-derived exosomes: A novel tool to treat therapy-refractory graft-versus-host disease. Leukemia 2014, 28, 970-973. [CrossRef] [PubMed]

154. Deun, J.V.; Mestdagh, P.; Sormunen, R.; Cocquyt, V.; Vermaelen, K.; Vandesompele, J.; Bracke, M.; Wever, O.D.; Hendrix, A. The impact of disparate isolation methods for extracellular vesicles on downstream RNA profiling. J. Extracell. Vesicles 2014, 3, 24858. [CrossRef]

155. Lener, T.; Gimona, M.; Aigner, L.; Börger, V.; Buzas, E.; Camussi, G.; Chaput, N.; Chatterjee, D.; Court, F.A.; Portillo, H.A.; et al. Applying extracellular vesicles based therapeutics in clinical trials-an ISEV position paper. J. Extracell. Vesicles 2015, 4, 30087. [CrossRef] 